\title{
Occurrence of the green sawfish Pristis zijsron in the Sudanese Red Sea with observations on reproduction
}

\author{
Igbal S. Elhassan* \\ University of Bahri, Fisheries Department, Khartoum, Sudan
}

\begin{abstract}
All sawfishes have undergone severe declines in numbers and ranges due to anthropogenic activities. Consequently, all species have been listed as Endangered or Critically Endangered by the IUCN. The aim of this study was to identify the species of sawfish that occur in the Sudanese Red Sea and to assess their current status. Encounter data from landing sites and markets (2000-2016) and bottom trawling along the southern coast (2015-2016) were compiled. In addition, data from rostra were obtained from private collections and museums (collected from 1969 to 2014). Only the green sawfish Pristis zijsron was identified based on 26 rostra of neonates, juveniles, and adults as well as 6 carcasses ( 1 juvenile, 5 adults). Based on necropsies of 5 adult females and 11 live neonates, parturition occurred from October to late April. The smallest female that had developing follicles was $350 \mathrm{~cm}$ total length (TL). The number of embryos per brood was 6; however, fishers reported broods of 2, 8, and 12. Size at birth ranged from 60 to $80 \mathrm{~cm}$ TL. Current nursery areas are Marsa Ashat, Marsa Trinkitat (Srinikitat), and Agig Bay along the southern coast, and Dungonab and Oseif bays along the northern coast. These areas should be targeted for protection (e.g. marine reserves, time-area closures) if conserving the remaining green sawfish in the region is a priority.
\end{abstract}

KEY WORDS: Pristis zijsron $\cdot$ Red Sea $\cdot$ Parturition $\cdot$ Nursery areas

\section{INTRODUCTION}

Sawfishes are a group of large batoid elasmobranchs and are considered some of the world's most endangered fishes (Dulvy et al. 2016). Although Compagno \& Last (1999) reported 7 species worldwide, Faria et al. (2013) concluded that the family consists of 5 valid species in 2 genera. Sawfishes occur worldwide in subtropical and tropical shallow coastal seas, estuaries, and freshwater systems (Compagno \& Last 1999). As elasmobranchs, the life history of sawfishes suggests that they have low rates of reproduction (Compagno \& Last 1999, Simpfendorfer 2000, Thorburn et al. 2004). All 5 species appear to have undergone severe declines in their geographical ranges due to anthropogenic activities

\footnotetext{
*Corresponding author: igbalelhassan@gmail.com
}

(Simpfendorfer 2000, Pogonoski et al. 2002, Peverell 2005, Seitz \& Poulakis 2006, Thorburn et al. 2007). As a result, all species are now listed as either Endangered or Critically Endangered by the International Union for the Conservation of Nature (Dulvy et al. 2016). In addition, all species are listed in Appendix 1 of the Convention on International Trade in Endangered Species of Wild Fauna and Flora (Vincent et al. 2014).

Historically, sawfishes have been documented in the Red Sea, and there is evidence for exploitation and trade in the region since the late 1800s and early 1900s (Spaet \& Elhassan 2014, Moore 2015). However, scientific surveys and research on sawfish in the region have been lacking. Recently, information on sawfish occurrence was obtained through inter-

() The author 2018. Open Access under Creative Commons by Attribution Licence. Use, distribution and reproduction are unrestricted. Authors and original publication must be credited. 
views with coastal fishers in Djibouti, Eritrea, Yemen, Saudi Arabia, and Sudan (Spaet \& Elhassan 2014). Sawfish abundance has severely declined in the Red Sea and the Gulf of Aden, with the only recent records from Sudan. Two species, the narrow sawfish Anoxypristis cuspidata and green sawfish Pristis zijsron, were reported from the region (Spaet \& Elhassan 2014). However, the only confirmed records were based on 3 rostra in the headquarters of the Ministry of Agriculture and Water, Marine Fisheries Department in Yanbu, Saudi Arabia, and 2 preserved specimens at the Marine Museum in Hurghada, Egypt (Bonfil 2002). Sawfish bycatch from trawling in Eritrea was reported in 2012 (A. H. Gebrihiwet pers. comm.), but the report did not specify the species or numbers caught.

The aim of this study was to evaluate the status of sawfishes in the Sudanese Red Sea for better man-

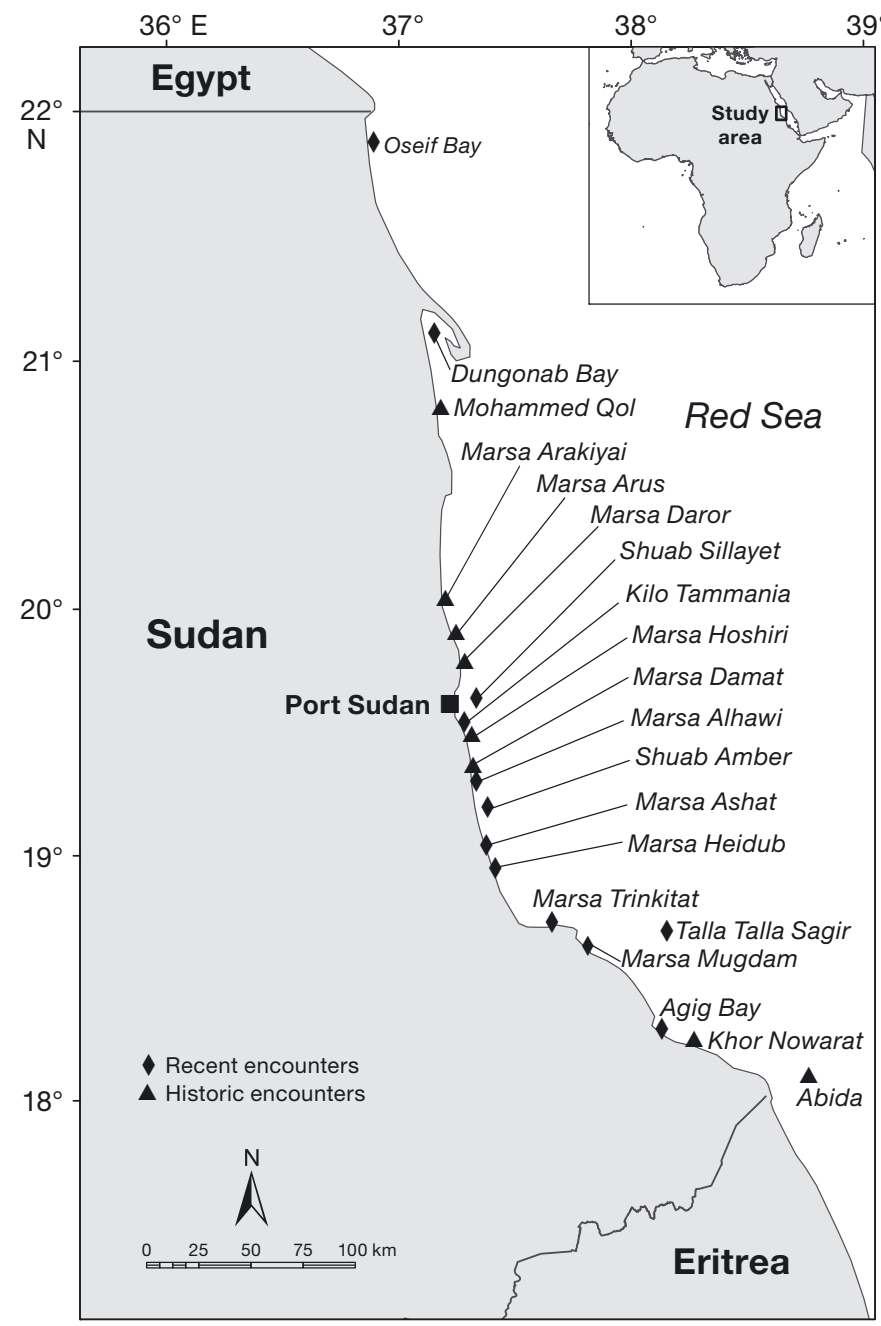

Fig. 1. Sudanese Red Sea coast, showing current and historically important areas for the green sawfish Pristis zijsron agement and conservation of these iconic species. Specific objectives were to (1) identify the species of sawfish in the Sudanese Red Sea, (2) determine habitat use in the region, (3) investigate reproductive biology, and (4) identify past and current nursery areas.

\section{MATERIALS AND METHODS}

\section{Study area and fishing methods}

The Sudanese Red Sea coast is $\sim 800 \mathrm{~km}$ long and extends from the Egyptian border in the north to the Eritrean border in the south (Fig. 1). It has 2 prominent features: coastal lagoons (or 'marsas') and reefs. Fringing reefs line the entire Sudanese coast except for the marsas and the Tokar Delta in the south (FAO 2008). Water temperature is about $22^{\circ} \mathrm{C}$ in winter and $33^{\circ} \mathrm{C}$ in summer. The Baraka River near the Eritrean border is the only river that reaches the Sudanese Red Sea.

Approximately 2000 professional fishers and 1000 recreational fishers operate along the Sudanese coast (Director of the Marine Fisheries Administration pers. comm.). In general, fishing along the Sudanese coast is artisanal, with seasonal bottom trawling from October to May by licensed Egyptian trawls ( $\mathrm{n}=15-$ 35) in a limited area along the southern coast. Gill nets, longlines, and hand lines are the commonly used types of fishing gear. Gill nets were introduced along the Sudanese coast by the British Overseas Development Agency in the late 1970s. Gill nets (multifilament and monofilament) are mainly used along the southern coast, whereas longlines and hand lines are typically used along the northern coast.

\section{Data collection and analysis}

In Sudan, sharks and sawfish targeted or captured as bycatch are rarely brought in whole; they are typically processed at sea and brought to the landing sites or fish markets as trunks. Therefore, obtaining information on life history characteristics, morphometrics, and measurements was not always possible. If available, the total length of sawfish was measured from the tip of the rostrum to the tip of the caudal fin. When there was only a rostrum and trunk, total length was estimated following Faria et al. (2013). The length of the rostrum was measured from the tip to its midpoint at the confluence of the rostrum and head (Whitty et al. 2014). Species identification of the 
rostra was based on the taxonomic characteristics described in Whitty et al. (2014). Species identification of the few whole sawfish was based on the taxonomic characteristics described by Faria et al. (2013). For female sawfish, maturity was estimated based on the development of follicles or presence of embryos in the uterus and for males by investigating calcification of the claspers. Tissue samples from rostra and fin clips were taken for genetic identification and stored in $98 \%$ ethanol at room temperature.

Because sawfish are rarely encountered, a network of fishers along the Sudanese coast was formed to provide information when encounters occurred. Fishers were also contacted in 2015 ( $\mathrm{n}=337$, ages 15 to 90 ) to inquire about encounters, and some of those data were reported here (i.e. reproduction, depth of encounters, historical occurrence). Landing site and market data were compiled from January 2000 to April 2016. During October 2015 to March 2016, data were also collected from bottom trawling along the southern coast. In addition, data from rostra were obtained from private collections (collected from 1969 to 1984), the Natural Museum of the University of Khartoum, and Sudanese universities (collected from 1999 to 2014). Rostra collected by the author were donated to the Natural Museum and 2 universities.

Timing of parturition was estimated based on finding full-term embryos in the uterus, or finding freeliving young with unhealed yolk sac scars. Fishers who captured or encountered sawfish were asked about the habitat where the fish were found, water depth, fishing gears used, and condition of the fish. Detailed information on the habitat where the sawfish were captured or encountered included the sediment type as well as type and density of seagrass.

\section{RESULTS}

\section{Species identification}

Morphological identification of 26 rostra from all life stages as well as 6 whole carcasses (1 juvenile, 5 adults; collected from 2000 to December 2015) confirmed the presence of the green sawfish Pristis zijsron in the Sudanese Red Sea. The range of rostral teeth was 29-31 on the right side and 30-35 on the left side. Six female rostra had the same number of teeth per side. The smallest rostrum, $17 \mathrm{~cm}$, was from a $60 \mathrm{~cm}$ total length (TL) neonate female that had 30 rostral teeth on both sides. The largest rostrum was $142 \mathrm{~cm}$ (31 rostral teeth on each side) and was from an individual with an estimated TL of $554 \mathrm{~cm}$.

\section{Encounter locations and habitats}

A total of 50 green sawfish, including neonates, juveniles, and adults, were captured as bycatch by fishers or seen by divers and fishers from 1997 to 2016 (Fig. 2). Five live adults were encountered by divers and fishers from 2007 to 2014, and there was a record from 1997 of a $250 \mathrm{~cm}$ TL male caught from Marsa Alhawi along the southern coast during a bony fish survey by the Marine Fisheries Administration (H. Shouf unpubl. data). Of the live adults mentioned above, all were seen in coral reef areas: 3 were encountered by 2 divers and a shell collector at Shuab Amber in water around $40 \mathrm{~m}$ deep, 1 at Shuab Sillayet in water $15 \mathrm{~m}$ deep, and 1 close to Marsa Daror. Two live sawfish were observed by fishers: 1 was resting on a sandy substrate outside a mangrove area in Kilo Tammania, $8 \mathrm{~km}$ from Port Sudan, and the other was resting on a sandy substrate with sparse stone in Agig Bay. Both were encountered at low tide. A young juvenile was captured in March 2016 in a trawl in the Talla Talla Sagir area along the southern coast (not included in Fig. 2). In April 2016, a young juvenile was caught as bycatch by a fisher fishing for bony fishes in Marsa Trinkitat on the southern coast (not included in Fig. 2).

\section{Timing of fishing and capture}

Thirty-eight of 44 sawfish were captured at night in gill nets and 4 were captured in the morning. Most fishers set their nets at night and haul them in the early morning. The fishers reported that all of the sawfish were found alive in the nets except for 1 juvenile that was found dead in a gill net. All captured sawfish were killed to detangle the rostra from the net. All were neonates or juveniles caught in monofilament gill nets as bycatch in the artisanal prawn fishery except for a $150 \mathrm{~cm}$ TL juvenile caught by hand line in the morning in Marsa Ashat. As mentioned above, 5 live adults were encountered by divers and fishers during the day. No information on the time of fishing was available for 3 of the captured sawfish.

\section{Water depth}

Twenty-three neonates, juveniles, and several adult female sawfish were captured or encountered in inshore water depths $\leq 10 \mathrm{~m}$ where there was a Khor (stream) that brought water flow from rain during the wet season from late October to April (Fig. 3). These 


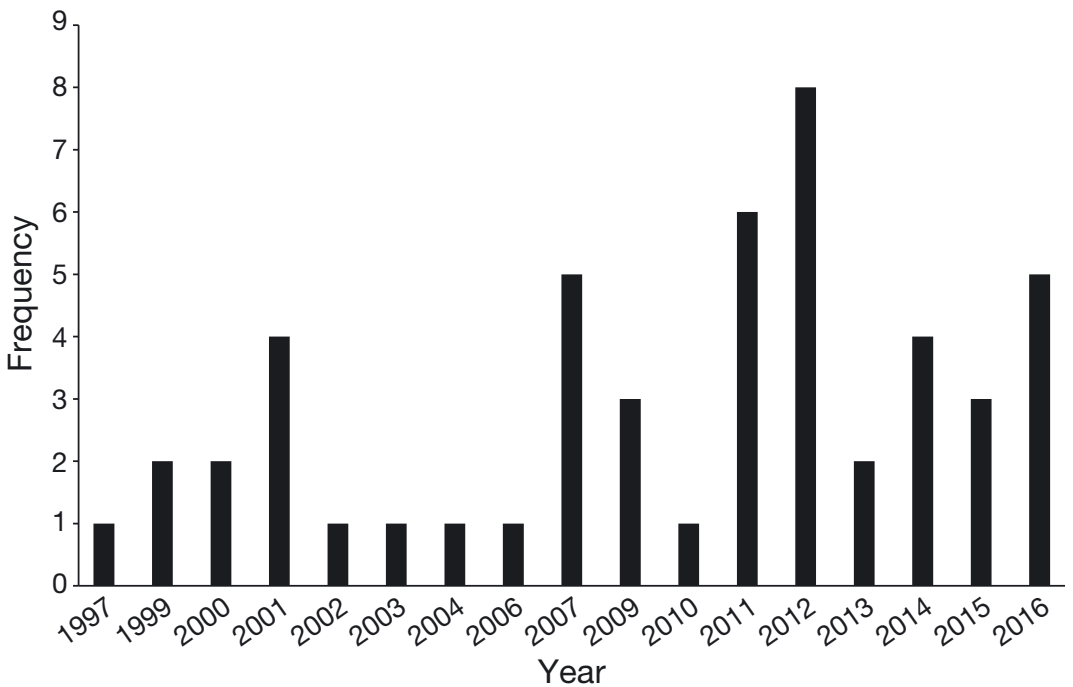

Fig. 2. Frequency of green sawfish Pristis zijsron encountered or captured from 1997 to $2016(n=50)$. Note that years containing no sawfish were omitted

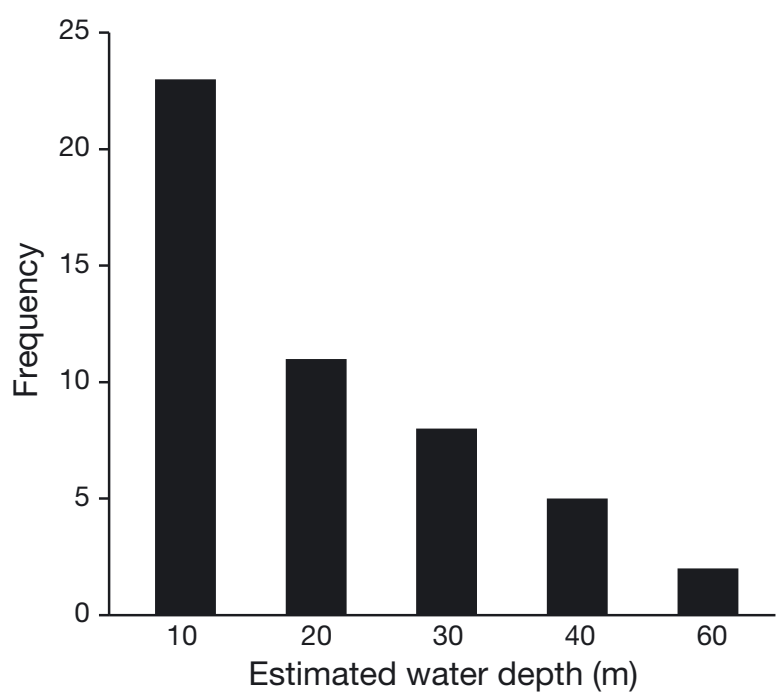

Fig. 3. Frequency of green sawfish Pristis zijsron encountered or captured $(n=49)$ in different water depths

areas were associated with mangrove stands. Large juveniles and adults were encountered in water 5 to $45 \mathrm{~m}$ deep. Sixteen percent of the captured adults were in water $30 \mathrm{~m}$ deep. However, a male $331.8 \mathrm{~cm}$ TL was captured from water $60 \mathrm{~m}$ deep in December 2014 in Tweeti.

\section{Sex and maturity stage}

Sex of sawfish encountered by divers or fishers was unknown except for a few individuals. In most cases, sawfish were processed at sea. When only the rostrum and the finned, gutted trunk were brought to the landing site, information on sex was provided by the fishers if possible.

The smallest mature female green sawfish encountered during the study was $350 \mathrm{~cm}$ TL (based on 3 gravid green sawfish and 2 with large vitellogenic follicles). The largest mature male was 386.1 $\mathrm{cm}$ (calcified claspers) and the largest immature male was $250 \mathrm{~cm}$ (claspers not fully calcified). The percentage of mature green sawfish among 44 captured sawfish (both sexes) was $46 \%$.

\section{Parturition and nursery areas}

Parturition of the green sawfish in the Sudanese Red Sea was from October to late April (the wet season), with a peak likely from December to March. Size at birth was estimated from full-term embryos that were 60 to 80 $\mathrm{cm}$ TL. The number of embryos per brood was 6 ; however, fishers reported broods of 2, 8, and 12 (eaten by the crew or thrown into the sea). Ten neonates between 81 and $89 \mathrm{~cm}$ TL were caught from Oseif Bay on the northern coast (January 2015 and March 2016), Marsa Ashat and Trinkitat along the southern coast (January 2015 and January to April 2016), and 1 from a trawl in Talla Talla Sagir (March 2016), providing further support for this recruitment period.

All interviewed fishers over age 60 confirmed that until the mid-1980s, all marsa (embayments) and bays along the Sudanese Red Sea were nursery areas for green sawfish (Fig. 1). Based on recent (20062016) findings of gravid females and neonates with unhealed yolk sac scars or young-of-the-year, current parturition and nursery areas for green sawfish in the Sudanese Red Sea are Marsa Ashat, Marsa Trinkitat, and Agig Bay along the southern coast and Dungonab and Oseif bays along the northern coast.

\section{DISCUSSION}

The narrow sawfish Anoxypristis cuspidata and green sawfish Pristis zijsron were both thought to have occurred historically in the Red Sea (Spaet \& Elhassan 2014, Moore 2015). However, no historical or current records were found for the narrow sawfish. Moore (2015) noted that records of the narrow sawfish were limited to the coasts of Iran, Pakistan, and 
Masirah Island (Oman). Moore (2015) investigated historic records and specimens in the Persian Gulf and the adjacent waters and noted that the green sawfish was the most frequently occurring species in the area. Based on the identification of 26 rostra and 6 whole carcasses in the present study, the green sawfish is likely the only sawfish that has ever occurred in the Red Sea.

Neonate green sawfish were captured by fishers in Red Sea estuaries. Similarly, juvenile smalltooth sawfish P. pectinata in Florida (USA) also use estuaries as nursery areas (Poulakis et al. 2011). Protection of estuarine habitats will be essential to ensure the long-term survival of remaining green sawfish populations. Juvenile green sawfish were typically encountered on muddy flats in inshore turbid water $1 \mathrm{~m}$ deep or less, similar to smalltooth sawfish and largetooth sawfish (Whitty et al. 2009, Poulakis et al. 2011). Also similar to other sawfish species (Poulakis et al. 2011), in most areas where green sawfish were captured, they were associated with mangrove stands that likely provide food and protection for the young. Adults were encountered inshore and offshore in a range of water depths (5-60 m). While the green sawfish is often found in shallow water (around $5 \mathrm{~m}$ ), the previously recorded maximum depth reported for green sawfish was 30-40 m (Compagno \& Last 1999, Wueringer et al. 2009). However, the present study recorded an adult male at $60 \mathrm{~m}$. Several females were captured offshore, in deeper water, away from mangroves, similar to narrow sawfish in the Gulf of Carpentaria, Australia (Peverell 2008), and smalltooth sawfish in Florida (Poulakis \& Seitz 2004). Eight fishers encountered adult green sawfish in shallow water in winter, and 2 were encountered on sandy substrate during ebbing tide. Adults may visit shallow estuarine waters seasonally for parturition or for reasons associated with the tidal cycle.

Although rostral tooth counts of some sawfishes are known to be sexually dimorphic (Wiley et al. 2008), this could not be determined for specimens in this study, as sex was usually not associated with rostra from private collections, and only a few males were captured during the study period. However, interestingly, rostra with the same number of teeth per side were from females. In addition, the largest green sawfish rostra (139 and $142 \mathrm{~cm}$ ) were from adults from the northern Sudanese coast, both estimated to be about $550 \mathrm{~cm}$ TL. The largest green sawfish collected in Australia was estimated to be $600 \mathrm{~cm}$ TL, with a rostrum length of $165.5 \mathrm{~cm}$ (Morgan et al. $2010,2011)$, so the presence of large adults in the
Sudanese Red Sea provides hope for recovery of the species in the region if mortalities can be minimized.

Size at maturity for green sawfish in Australia is about $300 \mathrm{~cm}$ TL for both sexes (Last \& Stevens 2009). Peverell (2008) reported 1 mature green sawfish from the Gulf of Carpentaria, Australia (380 cm TL; 9 yr old). In the Red Sea, sizes at maturity for both sexes appear to be about the same as those in Australia, because a $350 \mathrm{~cm}$ TL female was mature, a $250 \mathrm{~cm}$ male was not mature (claspers not fully calcified), and a $386.1 \mathrm{~cm}$ TL male was mature (fully calcified claspers). Size at maturity data are inherently difficult to collect, even on species such as the smalltooth sawfish that have been studied for many years, because size at maturity is still unknown for that species.

Encounters with neonates and juveniles indicated that there remains a reproducing population of green sawfish in the Sudanese Red Sea. Recruitment data suggest that parturition occurs in the wet season from October to late April with a peak from December to March. In southern Pilbara, a remote nursery area for green sawfish in Australia, neonates were found in October with unhealed yolk sac scars (Morgan et al. 2015). In the Red Sea, green sawfish brood sizes range from 2 to 12. In Australia, brood sizes are similar, with up to 12 young born during the wet season (January through July; Peverell 2008, Morgan et al. 2010, 2011). Size at birth is also similar between the Red Sea and Australia (60-80 cm TL; Morgan et al. 2015).

In recent years, juvenile green sawfish of varying size classes were found inshore close to Khors (streams) and associated with mangrove shorelines. These areas are likely used for parturition and subsequently as nurseries, similar to other sawfish species. Juvenile smalltooth sawfish spend their first 1-3 yr of life in estuaries, start life with a sedentary neonate period that is followed by ontogenetic movement within the nurseries, and move away from shallow nursery waters after the first few years of life to deeper waters (Poulakis \& Seitz 2004, Wiley \& Simpfendorfer 2010). Using the Heupel et al. (2007) definition of elasmobranch nursery areas, Agig Bay, Marsa Ashat, Marsa Trinkitat along the southern coast, and Dungonab and Oseif bays along the northern coast show evidence of current parturition and nursery areas for the green sawfish. Neonates less than $100 \mathrm{~cm}$ TL and juveniles less than $200 \mathrm{~cm}$ TL were encountered in these areas for 2 successive years, particularly from January to March. Morgan et al. (2010) found that at age 1, green sawfish were around $130 \mathrm{~cm} \mathrm{TL}$, and Peverell (2008) found that between age 1 and 5, green sawfish measured between 
128 and $225 \mathrm{~cm}$ TL. These data suggest that juveniles caught in the Sudanese Red Sea were up to age 2. These nursery areas are subjected to artisanal fishing and also to trawling in Agig Bay and near Mugadam Island. Therefore, these areas need to be targeted for protection (e.g. marine reserves, time-area closures) if conserving the remaining green sawfish in the region is a priority.

\section{CONCLUSION}

The green sawfish is the only sawfish species currently found in the Sudanese Red Sea. Once common in estuaries in the region until the late 1980s, they are now rarely encountered, except for occasional records from locations along the southern coast. Fisheries bycatch and loss of habitat (e.g. cutting of mangroves) for coastal development are factors that led to the decline of sawfish in the Sudanese Red Sea. Removal of productive mangroves in Marsa Ausheri and Marsa Damat, south of Port Sudan, for the construction of the Red Sea Free Zone in 2000, has contributed to the disappearance of sawfish as reported by interviewed fishers from these areas. Overgrazing by camels and mangrove trimming by nomads for fuel have also affected these trees along the southern coast. Mangroves at Kilo Tammania have been affected by poor road design and careless construction of recreational areas. In most coastal areas, construction of roads without bridges has blocked freshwater flow which brings sediment necessary for mangrove growth and could act as cues for gravid females to find the nurseries. Healthy ecosystems are necessary to promote sawfish recovery and sustain local fisheries. Helping fishers and developers understand the broad importance of reducing bycatch and maintaining habitats will be imperative in the near- and longterm, especially since there is growing evidence that sawfishes are philopatric (Phillips et al. 2011, Feutry et al. 2015, Feldheim et al. 2017 this Theme Section), meaning they have an innate association with specific nursery areas.

Future research will involve genetic analyses and surveying identified nursery areas and other similar habitats (e.g. in Eritrea) to assess the number of neonate and juvenile green sawfish as well as estimating their residence time in the nurseries. The Marine Fisheries Administration will be involved in these surveys to maximize survival and protection of habitats of this iconic fish. Even though shark fishing has been banned in Sudan since 2008 and protective measures against possession, trade, or sale of sharks and sawfish were strengthened in 2015, enforcement of these rules and continuing the awareness campaign to release live sawfish back to sea whenever they are encountered will play a key role in the success of these conservation efforts. In addition, marine parks such as Sanganaeb Atoll Marine National Park and Dungonab Bay-Mukkawar Island Marine National Park that further limit fishing and safeguard important habitats provide hope that this species can recover in Sudanese Red Sea waters.

Acknowledgements. I sincerely thank Dr. Gregg R. Poulakis for reviewing the manuscript and for his useful suggestions that greatly improved it. I also sincerely thank the Mohammed Bin Zayed Species Conservation Fund and Save Our Seas Foundation for the financial support that I received for my $\mathrm{PhD}$ project. This fund helped me indirectly collect data on sawfish in the Sudanese Red Sea from 2012 to 2014. I thank Rachel Scharer for assistance in creating the map using ArcGIS. This work was presented as part of the symposium 'Biology and Ecology of Sawfishes' at the 2016 annual meeting of the American Elasmobranch Society, which was supported by funding from the Save Our Seas Foundation, Disney Conservation Fund, and the American Elasmobranch Society.

\section{LITERATURE CITED}

Bonfil R (2002) Consultancy on elasmobranch identification and stock assessment in the Red Sea and The Gulf of Aden. Final report. Regional Organization for the Conservation of the Environment of the Red Sea and Gulf of Aden. www.persga.org/Files/Common/Fisheries/Sharks/ StockAssesment_Report_2002.pdf

Compagno LJV, Last PR (1999) Order Pristiformes, Pristidae - sawfishes. In: Carpenter KE, Niem VH (eds) FAO species identification guide for fisheries purposes. The living marine resources of the Western Central Pacific, Vol 3. Batoid fishes, chimaeras and bony fishes, Part 1 (Elopidae to Linophrynidae). FAO, Rome, p 1410-1417

*Dulvy NK, Davidson LNK, Kyne PM, Simpfendorfer CA, Harrison LR, Carlson JK, Fordham SV (2016) Ghosts of the coast: global extinction risk and conservation of sawfishes. Aquat Conserv 26:134-153

FAO (Food and Agriculture Organization of the United Nations) (2008) Fishery country profile. FID/CP/SUD

Faria VV, McDavitt MT, Charvet P, Wiley TR, Simpfendorfer CA, Naylor GJP (2013) Species delineation and global population structure of Critically Endangered sawfishes (Pristidae). Zool J Linn Soc 167:136-164

Feldheim KA, Fields AT, Chapman DD, Scharer RM, Poulakis GR (2017) Insights into reproduction and behavior of the smalltooth sawfish Pristis pectinata. Endang Species Res 34:463-471

Feutry P, Kyne PM, Pillans RD, Chen X, Marthick JR, Morgan DL, Grewe PM (2015) Whole mitogenome sequencing refines population structure of the Critically Endangered sawfish Pristis pristis. Mar Ecol Prog Ser 533:237-244

Heupel MR, Carlson JK, Simpfendorfer CA (2007) Shark nursery areas: concept, definitions, characterization and assumptions. Mar Ecol Prog Ser 337:287-297 
Last PR, Stevens JD (2009) Sharks and rays of Australia, 2nd edn. Harvard University Press, Cambridge, MA

Moore ABM (2015) A review of sawfishes (Pristidae) in the Arabian region: diversity, distribution, and functional extinction of large and historically abundant marine vertebrates. Aquat Conserv 25:656-677

Morgan DL, Whitty JM, Phillips NM (2010) Endangered sawfishes and river sharks in Western Australia. Report to Woodside Energy Ltd. WEL JA0006RH0085 Rev 0. Centre for Fish \& Fisheries Research, Murdoch University, Perth

Morgan DL, Whitty JM, Phillips NM, Thorburn DC, Chaplin JA, McAuley R (2011) North-western Australia as a hotspot for endangered elasmobranchs with particular reference to sawfishes and the Northern River shark. J R Soc West Aust 94:345-358

Morgan DL, Allen MG, Ebner BC, Whitty JM, Beatty SJ (2015) Discovery of a pupping site and nursery for critically endangered green sawfish Pristis zijsron. J Fish Biol 86: 1658-1663

Peverell SC (2005) Distribution of sawfish (Pristidae) in Queensland Gulf of Carpentaria, Australia, with notes on sawfish ecology. Environ Biol Fishes 73:391-402

Peverell SC (2008) Sawfish (Pristidae) of the Gulf of Carpentaria, Queensland, Australia. MSc thesis, James Cook University, Townsville

* Phillips NM, Chaplin JA, Morgan DL, Peverell SC (2011) Population genetic structure and genetic diversity of three critically endangered Pristis sawfishes in Australian waters. Mar Biol 158:903-915

Pogonoski JJ, Pollard DA, Paxton JR (2002) Conservation overview and action plan for Australian threatened and potentially threatened marine and estuarine fishes. Environment Australia, Canberra

Poulakis GR, Seitz JC (2004) Recent occurrence of the smalltooth sawfish, Pristis pectinata (Elasmobranchiomorphi: Pristidae), in Florida Bay and the Florida Keys, with comments on sawfish ecology. Fla Sci 67:27-35

Poulakis GR, Stevens PW, Timmers AA, Wiley TR, Simpfendorfer CA (2011) Abiotic affinities and spatiotemporal distribution of the endangered smalltooth sawfish, Pristis pectinata, in a south-western Florida nursery. Mar Freshw Res 62:1165-1177

Seitz JC, Poulakis GR (2006) Anthropogenic effects on the

Editorial responsibility: Gregg Poulakis (Guest Editor), Port Charlotte, Florida, USA smalltooth sawfish (Pristis pectinata) in the United States. Mar Pollut Bull 52:1533-1540

Simpfendorfer CA (2000) Predicting population recovery rates for endangered western Atlantic sawfishes using demographic analyses. Environ Biol Fishes 58: 371-377

Spaet JLY, Elhassan IS (2014) Geographical distribution and status. 7.3.2. Red Sea. In: Harrison LH, Dulvy NK (eds) Sawfish: a global strategy for conservation. IUCN Shark Specialist Group, Vancouver, BC, p 58-59

Thorburn D, Morgan D, Gill H, Johnson M and others (2004) Biology and cultural significance of the freshwater sawfish (Pristis microdon) in the Fitzroy River, Kimberley, Western Australia. Report to Threatened Species Network, Auckland

Thorburn DC, Morgan DL, Rowland AJ, Gill HS (2007) Freshwater sawfish Pristis microdon Latham, 1794 (Chondrichthyes: Pristidae) in the Kimberley region of Western Australia. Zootaxa 1471:27-41

Vincent ACJ, Sadovy de Mitcheson YJ, Fowler SL, Lieberman S (2014) The role of CITES in the conservation of marine fishes subject to international trade. Fish Fish 15: 563-592

Whitty JM, Morgan DL, Peverell SC, Thorburn DC, Beatty SJ (2009) Ontogenetic depth partitioning by juvenile freshwater sawfish (Pristis microdon: Pristidae) in a riverine environment. Mar Fresh Res 60:306-316

*Whitty JM, Phillips NM, Thorburn DC, Simpfendorfer CA, Field I, Peverell SC, Morgan DL (2014) Utility of rostra in the identification of Australian sawfishes (Chondrichthyes: Pristidae). Aquat Conserv 24:791-804

*Wiley TR, Simpfendorfer CA (2010) Using public encounter data to direct recovery efforts for the endangered smalltooth sawfish Pristis pectinata. Endang Species Res 12: 179-191

Wiley TR, Simpfendorfer CA, Faria VV, McDavitt MT (2008) Range, sexual dimorphism and bilateral asymmetry of rostral tooth counts in the smalltooth sawfish Pristis pectinata Latham (Chondrichthyes: Pristidae) of the southeastern United States. Zootaxa 1810:51-59. www.mapress. com/zootaxa/2008/f/z01810p059f.pdf

*Wueringer BE, Squire L Jr, Collin SP (2009) The biology of extinct and extant sawfish (Batoidea: Sclerorhynchidae and Pristidae). Rev Fish Biol Fish 19:445-464

Submitted: June 12, 2017; Accepted: November 03, 2017 Proofs received from author(s): March 9, 2018 